\title{
Effect of processing on some biochemical characteristics and storability of locust bean condiment
}

\author{
Daramola B.* and Osanyinlusi S. A. \\ Department of Food Technology Federal Polytechnic, P. M. B. 5351, Ado-Ekiti, Ekiti State, Nigeria.
}

Accepted 24 June, 2013

\begin{abstract}
Storage life of 'green' locust beans condiment is less than $72 \mathrm{~h}$ due to inherent high moisture content $(>55 \%)$ and vulnerability to peroxidation due to high fat content $(>37 \%)$. Therefore, elimination or significant reduction of moisture and fat should lead to increase in storage life hence studied. 'Green' locust beans condiment was dried and delipidated using three solvents. Assessment of some physiochemical, biochemical, sensory characteristics and shelf-life preliminary study on the preparation were conducted. Moisture content $(<10 \%)$ of samples was at the level that samples are stable to spoilage microorganism. Lipids were extracted using three solvents in the order of diethylether $>$ hexane $>$ methanol with concomitant increase in proportion of protein in the delipidated sample in comparison to non-delipidated sample. Analysis of sensory scores $(p=0.05)$ showed that diethylether extracted sample was the most preferred and methanol extracted sample the least preferred. Using off-odour perception as accelerated storage instrument, shelf-life model insight (scale factor $=28$ days, shape factor 3.8) was obtained using Weilbull distribution.
\end{abstract}

Key words: Locust beans condiment, poor storability, processing, biochemical characteristics, shelf-life model insight.

\section{INTRODUCTION}

The choicest condiment of natural origin for enhancing flavour of food products by the people of Western Nigeria is fermented locust beans (Parkia. biglobosa) indigenously called 'Iru'. Being the most important food condiment in West and Central Africa, its frequent usage suggests it could play a contributory role to the intake of proteins, peptides, amino acids and B-vitamins (Fetuga et al., 1973). A lot of research works notably by Odunfa (1981), Odunfa and Adewuyi (1985b) had been carried out on the process of production of locust bean condiment largely from microbiological or fermentation perspective.

At harvest, fermented locust bean is at its 'green' form. The condiment is characterised, first by high moisture content, hence vulnerable to spoilage by microorganism.
Second, by high fat content, therefore, prone to fat deterioration and its undesirable consequences. Third, the condiment is marked by offensive odour probably of phenolic and ammoniacal origin. These are thought to be the barrier responsible for poor storability and unfriendly odour of locust bean condiment. Thus, constitute a challenge and should be addressed. Therefore, it is envisioned that if fat and moisture could be eliminated or reduced significantly objectionable odour could be reduced and shelf life could be extended from its present 2 to 3 days and the envisioned spurred this study.

The objectives of the present study were to dry and delipidate locust bean condiment, evaluate effects on some physiochemical, biochemical compositions and determine shelf-life preliminarily. 


\section{MATERIALS AND METHODS}

Locust beans condiment was obtained from a local producer at the point of harvest. Hexane, diethylether and methanol were of analytical grade.

\section{Preparation of sample and solvent extraction}

Locust bean condiment was dried using air oven at a temperature of $50^{\circ} \mathrm{C}$ for $12 \mathrm{~h}$, and subsequently divided into 3 portions: 1st portion was milled, 2nd portion was grated into average particle size of $4 \mathrm{~mm}$ while the third portion was not reduced in size. Each $(40 \mathrm{~g})$ of the different particle size group was later extracted with $400 \mathrm{ml}$ of three solvents namely: hexane, diethylether and methanol for $8 \mathrm{~h}$ using soxhlet extractor. After solvent extraction process, the samples were dried in air oven to expel remnant solvents from samples. These were used for subsequent analysis.

\section{Methods of analysis}

\section{Proximate composition}

Proximate composition was determined using the method of the Association of Official Analytical Chemists (AOAC, 1990) method. Carbohydrate was obtained by difference.

\section{Determination of free amino acids}

Free amino acids in the partially defatted locust bean condiment and non-defatted samples were extracted with $80 \%$ ethanol $(v / v)$ in accordance with the method of Odibo et al. (1990). The free amino acids in the ethanolic extract were estimated using the ninhydrin colorimetric method (Rosen, 1957) using glycine as standard.

\section{Determination of reducing power}

Reducing power of each sample was determined in accordance with the method of Oyaizu (1986). Simply, each sample $(1 \mathrm{mg} / \mathrm{ml})$ in methanol $(2.5 \mathrm{ml})$ was mixed with sodium phosphate buffer $(\mathrm{pH}$ 6.6). the buffered sample was mixed with conditioning reagents $\left(1 \% \mathrm{~K}_{3}-\mathrm{Fe}-\mathrm{CN}_{6}, 10 \% \mathrm{TCA}, 0.1 \% \mathrm{FeCl}_{3}\right)$ centrifuged, diluted using distilled water and absorbance was measured at $700 \mathrm{~nm}$. Higher absorbance indicates a higher reducing power.

\section{Measurement of $\mathrm{pH}$}

The $\mathrm{pH}$ of samples was measured using Omega $\mathrm{H}$. $\mathrm{HP}_{\mathrm{x}}$ digital $\mathrm{pH}$ meter. Standardization of the meter was done using buffer solutions of $\mathrm{pH} 4$ and 9.

\section{Determination of titratable acidity}

Partially defatted locust bean condiment and non-defatted samples were prepared for and titrated with standard alkaline. Results were expressed as lactic acid equivalent (AOAC, 1990).

\section{Shelf-life study}

Off- odour was choosing as accelerated storage instrument for shelf-life model study, because off-odour release is a critical characteristic of locust bean condiment even when not spoilt hence could serve as accelerated study instrument for the condiment. Ten gram of each sample was tested over time for off-flavour development. Three panellists that are familiar with locust bean condiment were used to evaluate each sample for off-flavour development on a seven-point rate scale with category 1 indicating no-off flavour to category 7 indicating very strong off-flavour. On this scale an average of score of 2.5 or more was considered a highenough off-flavour score for the product to fail. Using this procedure, failure times were obtained for the products. The data obtained were subsequently used to compute shelf-life parameters of importance using Weilbull hazard plots (Maxima and Jagar, 1984).

\section{Sensory evaluation}

Using ranking method, partially defatted locust bean condiment and non-defatted sample (control) was carried out by 10 panelists comprised of students of the Department of Food Technology, Federal Polytechnic Ado-Ekiti. The panellists were selected based on the history of their familiarity with processing of locust beans condiment. Sensory attributes evaluated were: Colour, odour, taste, flow characteristics and overall acceptability. Ranks were converted to scores according to the method of Fisher and Yates (1942) as reported by Larmond (1979)

\section{Statistical analysis}

The converted scores were subjected to analysis of variance (ANOVA). When significant $(P=0.05)$ difference was observed, means were separated using Tukey's test (Snedecor, 1956).

\section{RESULTS AND DISCUSSION}

The results of some physiochemical and biochemical assessment of the partially defatted locust beans condiment is shown in Table 1. The moisture content (\%) ranged from 6.0 to 7.4 which suggest that the product is in water condition stable to food spoilage microorganisms. The value is also similar to each other within the efficiency of the air oven used. Similarly, the $\mathrm{pH}(6.2-6.9)$ of the products was similar to each other. The value is lower to the $\mathrm{pH}$ (8.9) of fresh fermented locust bean condiment earlier reported in literature by Kok et al. (1986) and Omafuvbe et al. (2004). The difference could be explained in terms of elimination of ammoniacal compounds responsible for the high $\mathrm{pH}$ of fresh condiment which was evaporated by the drying process carried out on the product.

Titrable acidity ( $\mu$ g lactic acid equivalent $/ g$ sample) of the defatted samples was high (12.07 to 18.89) in comparison to the low (6.30 to 12.60) values of the partially defatted samples. This suggests that the solvent and process used in lipid removal facilitate the removal of some acids most probability fatty acid present in the condiment. The importance of this is that it is important to carry out sensory test of the products since such fatty acids may have contributory role in condiment taste. A rough estimate of extractible lipid (\%) by the examined solvents using weight difference suggests that all the 
Table 1. Some physiochemical and biochemical characteristics of partially and non-delipidated locust bean condiment.

\begin{tabular}{clcccccc}
\hline Sample & Treatment description & $\begin{array}{c}\text { Moisture } \\
\text { content }\end{array}$ & $\begin{array}{c}\text { Amino } \\
\text { acids }\end{array}$ & $\begin{array}{c}\text { Reducing } \\
\text { power }\end{array}$ & pH & $\begin{array}{c}\text { Extractible } \\
\text { lipid }\end{array}$ & $\begin{array}{c}\text { Titratable } \\
\text { acidity }\end{array}$ \\
\hline 1 & Whole beans hexane & 7.90 & 541.80 & 208.33 & 6.5 & 4.20 & 12.60 \\
2 & Milled beans hexane & 6.00 & 680.30 & 223.96 & 6.2 & 27.95 & 10.24 \\
3 & Coarse beans hexane & 6.70 & 320.22 & 109.38 & 6.5 & 23.48 & 10.79 \\
4 & Whole bean diethylether & 6.50 & 380.50 & 177.08 & 6.6 & 19.65 & 10.79 \\
5 & Milled beans diethyether & 6.70 & 671.10 & 119.79 & 6.2 & 35.00 & 10.18 \\
6 & Coarse bean diethylether & 6.30 & 458.70 & 62.50 & 6.4 & 35.20 & 6.30 \\
7 & Milled $\mathrm{CHCl}_{3}$ - methanol & 6.0 & 588.00 & 93.75 & 6.4 & 35.13 & 6.57 \\
8 & Whole $\mathrm{CHCl}_{3}$ - methanol & 6.20 & 301.75 & 109.38 & 6.9 & 16.00 & 8.87 \\
9 & Coarse $\mathrm{CHCl}_{3}$ - methanol & 6.0 & 292.50 & 93.75 & 6.7 & 21.78 & 9.44 \\
10 & Milled control & 7.0 & 347.90 & 244.79 & 6.7 & $\mathrm{NA}$ & 18.89 \\
11 & Coarse control & 7.4 & 255.59 & 130.20 & 6.7 & $\mathrm{NA}$ & 15.11 \\
12 & Whole control & 7.2 & 283.30 & 151.00 & 6.6 & $\mathrm{NA}$ & 12.07 \\
\hline
\end{tabular}

Amino acid $=\mu \mathrm{g}$ glycine $/ \mathrm{g}$ sample; reducing power $=\mu \mathrm{g}$ ferulic acid equivalent $/ \mathrm{g}$ sample; extractible lipid $(\%)$ titrated acidity $=\mu \mathrm{g}$ lactic acid equivalent /g sample; moisture content (\%), NA = not applicable.

Table 2. Some aspects of proximate composition (\%) of partially and non-delipidated locust beans condiment (milled-samples).

\begin{tabular}{lccccc}
\hline Sample & Ash & Ether extract & Moisture & Protein & ${ }^{*}$ CHO \\
\hline Diethyl ether & 6.14 & 3.25 & 8.00 & 70.59 & 12.02 \\
Methanol & 5.68 & 9.06 & 7.50 & 63.68 & 14.08 \\
Hexane & 4.54 & 13.75 & 8.00 & 59.50 & 14.21 \\
Control & 3.69 & 34.77 & 8.50 & 34.50 & 13.54 \\
\hline
\end{tabular}

*Obtained by difference.

solvent remove lipids from samples in which diethylether solvates the highest amount of lipids. Because of highest surface area, the extracted lipid (\%) (Table 1) in mild samples was higher in comparison to samples with smaller surface area (coarse and whole been samples). Removal of lipid should exert resistance of product to lipid susceptible deterioration such as peroxidation.

In addition, the effect of partial removal of lipids on amino acid concentration, one of the process effects of fermentation in sample was assessed. It was found that delipidation resulted to higher amino acid concentration in the partially defatted samples. The values of amino acid for milled sample were higher than the value of the other samples. This is by proportion and not quantity because of the samples had the highest amount of fat/lipid extracted from them by the used solvents. Amino acids assessment is important in the sense that it gave the clue to the fact that solvent and process did not lead to leaching of total amino acids into the extraction solvents. Amino acids play nutritional and taste (sensory) roles in locust beans condiment.

The samples exhibited reducing power, and index of antioxidative activity. This suggests that drying and lipid removal of locust bean do not abrogates exhibition of antioxidative activity of the condiment. This argument is important from nutrition stand-point. However, a cursory look on the result on Table 1 showed that methanol extracted sample was characterised by the least reducing power. Considering the values obtained for reducing power, generally, removal of lipid did not erode the reducing power of the samples. With the exception of methanol extracted samples. This suggests that some of the contributors to reducing activity of locust bean condiment are polar in nature, and probably have been extracted by the polar solvent, methanol.

The proximate composition of the milled samples is shown in Table 2. The proximate composition of the controlled sample was similar to an earlier report by Omafuvbe et al. (2004) except for the moisture content. This is because dry sample was used in this study. A comparison of the proximate composition of de-lipidated sample and control sample revealed the efficacy of the lipid extraction solvents on the locust bean condiment sample with similar particle size and extraction conditions (time and temperature). All the solvents extracted fat from the samples when compared with the lipid content of the control sample (Table 1). Diethylether showed the highest propensity for removing lipid with hexane removing 
the least amount of lipid. This result suggests that some of the lipid in locust bean is likely to be of higher polarity than that could be extracted by hexane and with less polarity to than that could be extracted by methanol. Therefore, leaving more lipids to be extracted by diethylether.

The variation in values obtained for ash and protein contents was not due to quantitative changes in the samples but due to concentration changes. This is because removal of fat does not increase the quantity of protein but increases its proportion in these samples.

\section{Shelf-life studies}

The length of time during which an item or a food product performs satisfactorily is called its life (shelf). Shelf life of a product is of paramount importance for to the consumer and the producer. The changes that occur in physical or pure chemical substances can be described by Arrhenius equation. However, this model could not adequately describe changes that occur in biological materials such as food hence, the use of Weilbull distribution a versatile life distribution that has been used for food product. The details of mathematical principles and illustration of application of Weilbull distribution are well documented in Maxima and Jagar (1984) as follows.

\section{Mathematical theory of shelf- life model}

This was accomplished using facile experimental procedure. Treaty on statistical principles on Weilbull distribution is not aimed but to allude to transformation of the distribution to linear plot described as follows.

If the life of a product is governed by Weilbull distribution its probability density function (pdf) and cumulative density function (cdf) is given by

$F(x)=(\beta / \alpha \beta) x^{\beta-1} \exp (-(x / \alpha) \beta)$

$x>0$ since life of a product cannot be negative; where $\alpha$ and $\beta$ are scale and shape parameter of Weilbull curve. And

$F(x)=1-\exp (-(x / \alpha) \beta)$

When the Weilbull distribution is skewed the hazard function is given by

$h(x)=\left(\beta / \alpha^{\beta}\right) x^{\beta-1} x>0$

And cumulative hazard function is:

$H(x)=(x / \alpha) \beta x>0$

Equation (4) could be re-written to express time $x$ as a function of the cumulative hazard function

$H: X=\alpha\left(H(x)^{1 / \beta}\right.$

Or in log units of time $x$

$\log x=\log \alpha+(1 / \beta) \log H(x)$

Equation (6) describes a straight line with $\log \alpha$ as the intercept and $1 / \beta$ as the slope. Simply, these are the mathematical bases (linear equation) for hazard plot in which near linearity of plot suggest appropriateness or adequacy of the Weilbull model. Table 3 shows the age at failure, and hazard of the samples used in this study. The hazard plot cumulative hazard against time of failure of this data was accomplished using Weilbull hazard plot graph papers and the nearly obtained straight line was used to estimate scale $(\alpha)$ of the $x$-axis and shape of the curve $(\beta)$. No study in which shelf-life of locust beans condiment had been modelled using Weilbull probability distribution, hence unable to compare results. The scale value ( $\alpha=35$ days) gives insight to the span of shelf-life of tested product.

The scale value $(\alpha)$ represents the life of the product as governed by the Weilbull probability distribution. The probability density function can be used to calculate the probability that the life of a product does not exceed chosen amount of time which imply the probability of a products failure at or before time $x$. This could be used for predicting the shelf-life of the product.

Whereas, the shape value $(\beta=3.8)$ suggests that Weilbull pdf tends to be symmetrical around the median which approximates to 35 days. The data plot could be used to estimate the probability of product failure with view to take action if necessary. For instance, estimation from the plot revealed that chances exist that $50 \%$ of product will fail after the $28^{\text {th }}$ day. Bearing in mind that this is a preliminary study there are chances that the shelf life can be increased from the value determined herein by total delipidation and application of packaging and more importantly, the assessment was based on accelerated storage test using off-flavour that does not necessarily imply microbiological spoilage.

\section{Sensorial assessment}

The result of sensory scores of the milled samples and control samples is presented in Table 4. Regarding colour, methanol extracted sample is statistically different from other samples. However the score obtained for diethylether sample was the highest which implied the most preferred. Regarding flow characteristics or dryness or resistance to cake-up. There is a difference between the control sample and other samples. Diethylether extract had highest sensory score and significantly different from other samples and the control sample had 
Table 3. Storage-time failure data for partially and non-delipidated locust bean condiment.

\begin{tabular}{ccccc}
\hline Sample No. & Number of termination & Age at termination & Hazard 100/k & Cumulative hazard \\
\hline 1 & 12 & 14 & 8.33 & 8.33 \\
2 & 11 & 16 & 9.09 & 17.42 \\
3 & 10 & 17 & 10.00 & 27.42 \\
4 & 9 & 23 & 11.11 & 38.53 \\
5 & 8 & 29 & 12.50 & 51.03 \\
6 & 7 & 32 & 14.29 & 65.32 \\
7 & 6 & 34 & 16.67 & 81.99 \\
8 & 5 & 36 & 20.00 & 101.99 \\
9 & 4 & 40 & 25.00 & 126.99 \\
10 & 3 & 45 & 33.33 & 160.32 \\
11 & 2 & 53 & 50.00 & 210.32 \\
12 & 1 & 53 & 100.00 & 310.32 \\
\hline
\end{tabular}

Table 4. Sensory scores and visual description of partially and non-delipidated locust beans condiment (milled samples).

\begin{tabular}{lcccc}
\hline Sensory & \multicolumn{4}{c}{ Samples } \\
\cline { 2 - 5 } characteristics & Hexane & Diethylether & Methanol & Control \\
\hline Colour & $0.32^{\mathrm{a}}$ & $0.57^{\mathrm{a}}$ & $-1.03^{\mathrm{b}}$ & $0.14^{\mathrm{a}}$ \\
Flow property/fluidity & $0.10^{\mathrm{b}}$ & $0.91^{\mathrm{a}}$ & $0.02^{\mathrm{b}}$ & $-1.03^{\mathrm{c}}$ \\
Odour & $1.13^{\mathrm{a}}$ & $0.44^{\mathrm{ab}}$ & $-0.22^{\mathrm{bc}}$ & $-0.79^{\mathrm{c}}$ \\
Taste & $0.72^{\mathrm{a}}$ & $1.03^{\mathrm{a}}$ & $0.50^{\mathrm{a}}$ & $-0.54^{\mathrm{b}}$ \\
Overall acceptability & $-0.1^{\mathrm{b}}$ & $0.91^{\mathrm{a}}$ & $-1.03^{\mathrm{c}}$ & $0.22^{\mathrm{b}}$ \\
Visual description & Light yellow & Bleached white & Dark & Light dark \\
\hline
\end{tabular}

*Values not followed by the same letter in a row are significantly $(p=0.05)$ different.

the least score. The cake characteristics of the control sample could be accounted for by the presence of lipid, fat and oil in the sample which bound sample particles together. The odour of samples extracted using hexane and diethylether were preferred to the methanol and control samples. This suggests that lipids responsible for odouriferous compounds in locust beans condiment are probably non-polar. Because these are the group of lipids extracted using hexane and diethlether solvents.

All the delipidated samples significantly taste better than the non- delipidated sample. This is reasonable since removal of lipid lend increase in concentration of protein, amino acid and peptide which are responsible for flavour of the tastant. In overall, sample extracted using diethylether, was most preferred while methanol extracted sample was least preferred, ranked behind control sample. This human judgment was informed by the appearance of methanol extracted sample which appeared black and as a result not appealing to the panels as shown by their comments in the questionnaire. It is known that when locust bean condiment is dried it turns dark in colour due to reaction between amino acid and carbonyl group of carbohydrate or fat as observed in this study, but the sample extracted using methanol was much darker. This suggests that methanol has promoted the carbonyl-amino reaction to produce the black pigments. The veracity of this speculation needed to be established. Visual colour of samples extracted with diethylether and hexane is also presented in Table 4.

\section{Conclusion}

Drying and partial delipidation resulted to product with minimal amount of moisture and fat with increased proportion of protein and ash content and consequently prolonged the shelf life of fermented locust beans condiment as revealed by shelf-life preliminary study. The process significantly improved sensory characteristics notably colour and odour of the condiment.

\section{REFERENCES}

AOAC (1990). Official Methods of Analysis 14th Edition. Association of Official Analytical Chemists, Washington DC.

Fetuga BL, Babatunde GM, Oyenuga VA (1973). Protein quality of some Nigerian food stuffs-chemical assay of nutrients and amino acids composition. J. Sci. Food. Agric. 24:1505-1510.

Kok R, Ikenebomeh MJ, Ingram JM (1986). Processing and fermentation 
of the African locust bean. (Parkia filicoidea Welw.) to produce dawadawa. J. Sci. Food. Agric. 37:272-282.

Larmond E (1979). Laboratory Method of Sensory Evaluation of Food () department of Agriculture, Ottawa, Canada. P. 1637

Maxima CG, Jagar S (1984). Statistical methods in food and consumer research. Academic Press Inc Orlando Florida. pp. 274-311.

Odibo FC Nwabunnia F Osuigwe DI (1990). Biochemical changes during fermentation of Telfaria seeds for ogiri production. World $\mathrm{J}$. Microbiol. Biotechnol. 6:425-427.

Odunfa SA (1981). Microorganisms associated with fermentation of African locust bean during in preparation. J. Plant Foods 3:245-250.

Odunfa SA, Adewuyi EY (1985b). Optimization of process conditions for the fermentation of African locust bean (Parkia biglobosa) $\mathrm{H}$. Effect starter cultures. Chem, Mikrobiol, Technol Lebensm 9:118-122.
Omafuvbe BO, Falade OS, Osuntogun BA, Adewusi SRA (2004). Chemical and Biochemical changes in African locust bean (Parkia biglobosa) and melon (Citrullus vulgaris) seeds during fermentation to condiments. Pak. J. Nutr. 3:140-145.

Oyaizu M (1986). Studies on extracts of browning reaction: Antioxidative activities of extracts of browning reactions prepared from glucosamine. Japan J. Nutr. 44:307-315.

Rosen H (1957). A modified ninhydrin Colorimetric Analysis for amino acids. Arch. Biochem. Biophys. 67:10-15.

Snedecor GW (1956). Statistical Methods Applied to Experiments in Agriculture and Biology, 5th ed. Ames, IA: State College Press. 